\title{
Physical Education Curriculum for Early Childhood: Developing Students' Manipulative Skills in Soccer
}

\author{
M.A. Al Ardha ${ }^{\mathrm{a}, 1}$, C.B. Yang ${ }^{\mathrm{b}, 2}$, K.R. Adhe ${ }^{\mathrm{c}, 3}$, F.D. Khory \& T. Harianto ${ }^{\mathrm{d}, 4}$, K.P. Putra ${ }^{\mathrm{e}, 5}$ \\ aDepartment of Curriculum Design and Human Potential Development, National Dong Hwa University, Taiwan \\ ${ }^{b}$ Department of Physical Education,National Dong Hwa University, Taiwan \\ ${ }^{\mathrm{c}}$ Department of Early Childhood Education, Universitas Negeri Surabaya \\ ${ }^{\mathrm{d} D e p a r t m e n t}$ of Physical Education, Universitas Negeri Surabaya, Indonesia \\ e Department of Physical Education,Universitas Kristen Satya Wacana, Indonesia \\ ${ }^{3}$ kartika.rinakit@gmail.com
}

\begin{abstract}
Introducing soccer for early childhood students is very beneficial, because they are in the range of golden ages in learning development. This research aims to find the proper strategy to help students get the benefit on learning passing, dribbling and shooting in soccer. By a quasi-experimental study, there were 28 students involved into 160 minutes treatment. They were also tested by Soccer Manipulative Skill Test (SMS Test). Its result showed that there is no significant different on the result of pretest passing and pretest shooting between male and female; there is different on the result of the pretest of drilling, male performance was better than female. However, after the treatment, male significantly performed better in the post test of passing, dribbling and shooting than female $(\alpha<.05)$. Moreover, the result of posttest in every manipulative skill is significantly better than pretest $(\alpha<.05)$. In conclusion, Physical Education curriculum effectively improves the students' achievement in soccer's manipulative skills.
\end{abstract}

Keywords—physical education curriculum; manipulative skill

\section{INTRODUCTION}

\section{A. Background}

Manipulative skill is an important basic ability for children, because it will help them to give some basic ideas and abilities before they go and learn for the more complex skill in the specific sport. The frequency and accuracy of practicing this fundamental skill is an issue, because in Indonesia early childhood school does not provide physical education class for their students. It is caused by many factors; two of them which become general issues are about the government regulation and school resources. Indonesian government does not have any physical education curriculum especially for childhood education, so the school does not get any support from the government to host the lesson for their students. In addition, early childhood has limitation in the human resources. The teacher in early childhood education usually does not receive any specific education or training about physical activity and exercise, so they do not have the complete idea to run a physical education class. It becomes an issue especially when we consider the students need specifically and carefully about kinds of treatments to avoid some disadvantages from the physical activity and exercises.

However, it is very important to have physical education in early childhood, because it provides more chances for students to practice and develop their ability by several kinds of physical exercises. The physical education in the golden age is a perfect combination to reach the best benefit, because it will not only give beneficial for the students in the physical and motor development, but also in social, emotional and cognitive development. It is also recognized that ages of 6 to 14 is the range of golden years in learning soccer [7]. The reason is that, after 14 years old, it is very difficult to correct improper technique-largely because of the extraordinary strength of habit development. This is also concerning about physical education in early childhood education, so this research aims to develop an ideal lesson plan of physical education by using soccer as the theme.

\section{B. Early Childhood Education}

Early childhood is children in the range age of 0-6 years old. They are in the process of unique and extraordinary development and growth, which are supported by the golden era or golden age. So they can learn and develop faster compared with when they are in out of the golden age. In order to maximizing the early childhood development, it requires proper education in each stage to optimize all of its capabilities (Indonesian Health Department, 2005). Early childhood education is a fundamental education at early childhood, given various stimuli to help the growth and development of the cognitive, social, emotional, physical, motoric and spiritual in order to have the readiness before continue the formal education in later life (Indonesia Ministry of Education, 2003). So 
early childhood education is a field of study that is studying ways to be effective in helping children of early age in order to grow and develop optimally.

One of the expected ability to grow and attach to the children in the long run of the entire path of education is motor learning or psychomotor aspect. In the motor development, there are two important laws to know and follow. They are the law of cephalocaudal and proximodistal (DeHart, Sroufe, \& Cooper, 2004). Cephalocaudal law development explained that human being grow from head to toe. This means that progress in structure and function occurs first of all in the head and the body then the last is leg. The second law is proximodistal developments. This law believed that human beings grow from close to far, from the main parts to the secondary; heart, lungs to hand and leg. It emphasized on the direction and pattern of motor development. However, to support the development, stimulation is highly needed. Stimulation is an ability and support facility that could spur motor development. It is very important for children to have a good stimulation, because it serves reinforcement for the realization of the potential that exists in children (Mayer, et. al., 2013). Physical exercise can be a good stimulator, because it plays a very vital role for childhood to give benefit on physical, motor, intellectual, social and emotional (Nurhasan et al, 2005: 1).

In particular, children aged 2-6 years experienced rapid progress in motor skills by playing. By playing, gross motor skills involved large muscles and fine motor skills as a result of the coordination of the small muscles in the eye and the hand (Hari, 2012: 185). The other benefit of well-structured playing, especially in physical education class is that, it could improve advantages and safety of these activities (Laker, 2001: 29). However, the educator should consider every detail chances in selecting the appropriate game to support children development [1]. That is because every children has different basic experiences and skills before participating in physical education class, it is based on their natural development and through play (Hopper, Grey, \& Maude, 2005: 10). A good stimulator of motor development should be possibly implemented.

\section{Manipulative Skill}

Manipulative skills are those skills that involved control of an object such as a ball, beanbag, hoop, rope, ribbon and frisbee. Most of these skills use the hand and feet, but other parts of the body can also be used. Manipulative skills develop hand-eye and foot-eye coordination which are particularly important for tracking objects in space (McKEnzie, Alcarazm, \& Sallis, 1998: 328). Manipulative skills include throwing, catching, kicking, trapping, striking, volleying, rolling, and dribbling. They are referred to as complex motor skills. Com- petence in manipulative skills generally occurs at a later stage than locomotor skills because of the need for complex hand eye and foot eye patterns required tracking and intercepting a moving object.

However manipulative skills do not develop automatically. It needs lots of opportunities for instruction and practice so that students become competent in doing manipulative skills. The development of manipulative skills leads to students become more actively involved in games and play activity. Competence in manipulative skills can improve students' selfesteem, peer acceptance and easy transition into local community and outside of school environments.

In this study the manipulative skills which will be observed is soccer game. There are three manipulative skills on this sport, namely; passing, dribbling, and kicking. By mastering these skills, students are expected to have more opportunities to join and enjoy soccer in the future. The reason is that, these three skills are stated as the fundamental soccer manipulative skills that will be used in most of soccer player position. However, the most important key of soccer besides those skills in this age is fun and enjoy [3], so that the children feel enjoy when they are trying to perform those skills.

\section{Soccer}

Soccer and football are similar. It is the world's most popular game which is played and watched by the most population in the world [15]. However, Soccer is American term is called football. There are at least 7 main skills in soccer. They are dribbling, receiving, passing, shooting, heading, tackling and goalkeeping. However, this study focuses on the three skills that are commonly used by most of soccer players in every position. These three skills are also called as the backbone of the game [3]. They are passing, dribbling and shooting.

\section{E. Passing}

Passing is the skill which is played to deliver the ball to the partner with high demand of accuracy and precision [7]. In soccer, passing ability must be developed in every practice session to some degree [8], since it is used mostly in the soccer game. This skill is usually combined with receiving. When there is a player passes the ball, another player has to receive the ball. In the receiving the ball, players can use our foot, legs, abdominal, chest, shoulder, and head. Nevertheless, for this study, the authors used foot to trap and stop the ball. In definition, foot trapping is stopping the ball by turning the foot sideways to receive the ball from others [3].

\section{F. Dribbling}

Dribbling means moving and controlling the ball to the certain place in order to control the game or to attack. This 
skill is very important technique for young players to develop [8]. Further, especially, when they learn to perform in controlling the ball direction such as turning left and right. It can be performed by using the inside or outside of feet to cut inside (the inside of right foot to turn to your left) and cut outside (the outside of right foot to turn to your right) [3].

\section{G. Shooting}

Shooting is the ability to kick the ball inside the goal. The most powerful and accurate shoots are the ones that come from clean strikes of the ball. However, accuracy is more important than power (Borden, 2009: 143).

\section{METHOD}

This is a quantitate study with quasi-experimental research design. This study involved 28 kindergarten students in age 6 $( \pm 0.4)$ years old. The students consist of 12 males and 16 females. It uses pretest and posttest data collecting methods by using Soccer Manipulative Skill Test (SMS Test) Procedure (Appendix 1). The treatment was conducted in two times meeting of physical education class with total duration 160 minutes. The treatment is written in the physical education lesson plan (Appendix 2). The data was analyzed by SPSS 20.0 computer software. The data analysis includes KolmogorovSmirnov test, independent sample t-test, and paired t-test.

\section{RESULTS AND DISCUSSION}

The data of student achievement in the Soccer Manipulative Skill Test is normal. The significant value is more than .05. Furthermore, the independent t-test and paired t-test results are shown in the table 1 . For independent t-test, it compares the differences between male and female achievement in every test. Moreover, paired t-test compares the differences between pretest and posttest in every skill.

TABle I. Soccer Passing Skill Test Result

\begin{tabular}{|l|c|c|}
\hline & Pretest & Posttest \\
\cline { 2 - 3 } & Passing & Passing \\
\hline Sig.of Normality & 0.056 & 0.179 \\
\hline Total mean & 2.429 & 3.357 \\
\hline Mean Male & 2.750 & 4.000 \\
\hline Mean Female & 2.188 & 2.875 \\
\hline $\begin{array}{l}\text { Sig.of Independent } \\
\text { Test }\end{array}$ & 0.077 & $0.002^{*}$ \\
\hline Sig.of Paired test & $0.000^{*}$ & \\
\hline
\end{tabular}

significant $<.05$
TABLE II. SOCCER DRIBBLING SKILl TEST RESUlT

\begin{tabular}{|l|c|c|}
\hline & Pretest & Posttest \\
\cline { 2 - 3 } & Dribbling & Dribbling \\
\hline Sig.of Normality & 0.064 & 0.187 \\
\hline Total mean & 2.357 & 3.286 \\
\hline Mean Male & 2.917 & 3.833 \\
\hline Mean Female & 1.938 & 2.875 \\
\hline $\begin{array}{l}\text { Sig.of Independent } \\
\text { Test }\end{array}$ & 0.077 & $0.005^{*}$ \\
\hline Sig.of Paired test & $0.000^{*}$ & \\
\hline
\end{tabular}

TABLE III. SOCCER SHOOTING SKILl Test RESUlT

\begin{tabular}{|l|c|c|}
\hline & Pretest & Posttest \\
\cline { 2 - 3 } & Shooting & Shooting \\
\hline Sig.of Normality & 0.099 & 0.084 \\
\hline Total mean & 2.393 & 3.571 \\
\hline Mean Male & 2.667 & 4.167 \\
\hline Mean Female & 2.188 & 3.125 \\
\hline $\begin{array}{l}\text { Sig.of Independent } \\
\text { Test }\end{array}$ & 0.134 & $0.004^{*}$ \\
\hline Sig.of Paired test & $0.000^{*}$ & \\
\hline
\end{tabular}

There is no significant different on the result of passing pretest and shooting pretest between male and female. Only in the pretest of drilling, male performed better than female. However, after the treatment, male significantly performed better in the post test of passing, dribbling and shooting. Finally, the result of posttest in every manipulative skill is significantly better than the result of pretest.

\section{A. The Accuracy of Passing}

\section{CONCLUSION}

The result of pretest in the passing and shooting shows that there are no significant differences between male and female. On the other word, the basic students' capability in the passing and shooting before the treatment between male and female are the same, because both of the manipulative skills require accuracy as the main element to perform both of those skills [8]. And it can be improved by doing more practice to get the common sense of accuracy in passing and shooting [3].

The technique of the kicking the ball is also an issue to get the accuracy. Most of the students kick the ball with their toe. As the result, the ball direction is uncontrolled. Likewise, it also relates with the difficulty of controlling the power. This finding was solved by introducing to the students about the 
correct impact when they do passing or kicking. The flat inside face of the foot is the most appropriate impact part with the ball to produce the accurate direction and fully control power [15]. Additionally, the non-kicking foot placed comfortably beside the ball - toe pointing to the target [8].

\section{B. Practice makes perfect}

Based on the finding of this study, the treatment gives a positive effect on the students' achievement in the SMS Test. There is a significant improvement on the result of posttest in every skill. This result could be assumed that the treatment gives constructive effect on the skill development. However, the treatment or practice actually only gives a short stimulation for the students to perform those skills better. Long term practice in soccer will give more benefit on improving those skills better [8]. More than that, practice playing soccer also gives the positive respond on muscle skeletal structures to the weight-bearing and impact-loading imposed [11]. In addition, it is better for school in providing soccer extracurricular for the students, so that they do not only practice in physical education class. Because participation in soccer extracurricular activities may help students engaged with learning and enhance a school's academic profile [12].

\section{Gender Achievement}

The result of pretest in the passing and shooting shows that there is no significant difference between male and female achievement. However, male students' achievement in posttest is significantly better than the female students, even though there is also an improvement in overall posttest result. This could be caused by the treatment was not effective for the female students. So that male students improve better than the female. The other reason is maybe the willingness of participation on giving treatment for female students is not as good as male students. Male students are more risk taker than female students [9]. It is maybe also correlating with the high change of getting injury of the soccer. It was proven by Schiff (2007: 369 ), he found that $44.6 \%$ of female youth soccer players had ever been injured [10].

Beside the change of getting improvement on those skills, the chance of injury is also high. In this case, the teacher has to be careful in instructing students to practice in the outdoor [9]. Moreover, children's and parents' understanding on playing outdoor contribute to decrease the chance of getting injury [9].

\section{REFERENCES}

[1] R.T. Alawiyah, Peningkatan keterampilan Motorik kasar Melalui Permainan Tradisional Banten, Jurnal Pendidikan Usia Dini, Jakarta: UNJ Press, pp. 175-184, 2014.

[2] D. Ary, L.C. Jacobs, and C.K. Sorensen, Introduction to Research in Education: Eighth Edition, Belmont, USA: Wadsworth, Cengage Learning, 2010.
[3] S. Borden, The Complete Idiot'S Guide to Soccer Basic, Indianapolis, USA: Alpha Book- Penguin Group, 2009.

[4] A. Burggraff, Developing Discipleship Curriculum: Applying The Systems Approach Model for Designing Instruction by Dick, Carey, and Carey To The Construction Of Church Discipleship Courses. Christian Education Journal, 12(2), 397-414. Retrieved from http://search.proquest.com/docview/1725036343?accountid=10534 [2015]

[5] Carroll, Bob. Assessment in Physical Education: A Teacher's Guide to the Issues. Bristol, USA: The Falmer Press, 2005.

[6] E.A. Jambor, "Parents as children's socializing agents in youth soccer," Journal of sport behavior, vol. 22, no. 3, pp. 350, 1999.

[7] J. Lennox, J. Rayfeld, and B. Steffen, Soccer Skills \& Drills: National Soccer Coaches Association of America. United States: Human Kinetics, 2006.

[8] J. Martin, The Best of Soccer Journal: An NSCAA Guide to Soccer Coaching Excellence, Germany: Meyer \& Meyer Sport (UK) Ltd, 2012.

[9] B.N. Rosen and L. Peterson, Gender Differences in Children'S Outdoor Play Injuries: a Review and an Integration. Clinical Psycho\&y Rmirw, vol. 10, pp. 187-205, 1990.

[10] M.A. Schiff, "Adolescent health brief Soccer Injuries in Female Youth Players," Journal of Adolescent Health, vol. 40, pp. 369-371, 2007.

[11] A. Seabra, E. Marques, J. Brito, P. Krustrup, S. Abreu, J. Oliveira, C. Rêgo, J. Mota, and A. Rebelo, Muscle strength and soccer practice as major determinants of bone mineral density in adolescents. Joint Bone Spine, vol. 79, pp. 403-408, 2012.

[12] E, Stearns, and E.J. Glennie, "Opportunities to participate: Extracurricular activities' distribution across and academic correlates in high schools," Social Science Research, vol. 39, pp. 296-309, 2010.

[13] M.C.T. Teixeira, and L.A. Teixeira, Leg preference and interlateral performance asymmetry in soccer player children. Developmental psychobiology, vol. 50, no. 8, pp. 799-806, 2008.

[14] J. Vincent, and F.D. Glamser, "Gender differences in the relative age effect among US Olympic Development Program youth soccer players," Journal of sports sciences, vol. 24, no. 4, pp. 405-413, 2006.

[15] J. Wesson, The Science of Soccer. London, UK: MPG Books Ltd, Bodmin, Cornwall, 2002. 